\title{
OTORITAS DAN AKUNTABLITAS DANA PENDIDIKAN
}

\author{
Zailani \\ Fakultas Agama Islam Universitas Muhammadiyah Sumatera Utara \\ Jl. Kapten Muhktar Basri No 3 Medan. \\ jai_ananda45@yahoo.co.id
}

\begin{abstract}
Abtsrak: Otoritas dan akuntabilitas dana pendidikan merupakan bagian utama dalam membentuk pendidikan yang maju dan andal. Perlu penjelasan yang riil bagaimana pihak otoritas yang akuntabel dalam mengeluarkan dana dan pengawasan keluar masuknya dana pendidikan. Pengelolaan dana pendidikan dengan baik akan berpengaruh kepada langsung kepada output dari lembaga pendidikan itu sendiri. Sebagai seorang otoritator, kepala sekolah mempunyai peranan yang strategis untuk menjaga keluar masuknya dana dilembaganya. Sinergitas dengan segenap elemen pendidikan menjadi kekuatan tersendiri. Disisi yang lain keberadaan komite sekolah selalu menjadi pemantau, pengawas dan pembimbing.
\end{abstract}

Kata kunci : Otoritas, Akuntabilitas dan Pendidikan

\section{Pendahuluan}

Pendidikan merupakan wadah pembentukan karakter bangsa. Tanpa pendidkan yang baik maka perwujudan unuk menjadi Negara besar dan berwibawa suit sekali tercapai. Peranan Pendidikan yang begitu besar menjadikan lembaga ini menjadi perhatian pemerintah untuk" memuliakan"nya dengan segala kebijakannya. Salah satu upaya tersebut diimplementasikan dalam bantuan dan alokasi anggaran yang baik untuk mensupport hal tersebut. Supaya pendistribusian anggaran berjalan dengan baik, diperlukan sikap bertanggung jawab dari berbagi pihak yang mengelola secara langsung maupun tidak.

Menumbuhkan kembangkan kualitas suatu lembaga pendidikan disekolah diperlukan sikap terbuka dan kejelasan terkait yang berhubugan dengan pengelolaan keuangan baik yang lembaga pendidikan negeri ataupun swasta. Ditinjau dari sudut pengelolaan dana di lembaga pendidikan, semisalnya sekolah. Kualitas terleatak seberapa efesien dana yang didapat baik dri pemerintah atau dri sumber lain. Maka keberadaan kepada Sekolah dan komite sangat berperan besar dalam menjaga keluar- masuknya dana disebuah sekolah.

Leadership yang dikembangkan kepala sekolah yang sekaligus penanggung jawab dalam penggunaan anggaran menjadi kemestian yang tak 
terbantahkan, bahwa baik-buruknya sebuah lembaga pendidikan. Dalam internal sekolah tergantung dari pemimpin utama. Karena perputaran dana yang dianggarkan harus menyentuh dalam ranah kebutuhan sekolah, yang meliputi peningkatan kualitas guru, pengembangan peserta didik dan pemeliharaan fisik sekolah. Dengan demikian diperlukan prinsip akuntablitas untuk menjaga aliran dana dari hulu sampai hilir. Sudah seyogyakan Kepala sekolah menjadi teladan dalam penyerapan dan sirkulasi dana disekolah dapat menjaga indentitas sekolah sebagi bagian lahirnya generasi dengan berbagi ketrampilan dan dimbangi dengan nilai luhur.

\section{Pengertian Otoritas dan Akuntabilitas}

Dalam kamus besar bahasa Indonesia, Otoritas diartikan sebagai: 1. Kekuasaan yang sah yang diberikan kepada lembaga dalam masyarakat yang memungkinkan para pejabatnya menjalankan fungsinya; 2. Hak untuk bertindak; kekuasaan, wewenang; hak untuk melakukan tindakan atau hak membuat peraturan untuk memerintah orang lain. ${ }^{1}$ Otoritas atau dalam bahasa Indonesia lebih dikenal dengan sebutan wewenang merupakan suatu pengertian yang kompleks. Tidak berbeda jauh dengan apa yang diungkapkan oleh beberapa ahli. ${ }^{2}$

${ }^{1}$ Depertemen Pendidikan Nasional, Kamus Besar Bahasa Indonesia ( Jakarta: Pustaka Utama, 2008), h. 992.

2 Robert Bierstedt dalam bukunya Analysis of Social Power menyatakan: "wewenang adalah kekuasaan yang dilembagakan" Harold D. Laswell dan Abraham Kaplan menyatakan: "wewenang adalah kekuasaan formal" .lihat Harold D Laswel dan Abraham, Power and Society Stepphen (USA: Transcation Publisher, 1950), h. xi. P. Robbins dalam bukunya Organisational Theory yang menyatakan bahwa wewenang adalah hak untuk bertindak atau untuk memerintahkan orang lain untuk bertindak ke arah pencapaian organisasi. Max Weber mengusulkan teori otoritas yang mencakup tiga jenis dalam esainya "Tiga jenis pemerintahan yang sah". Tiga jenis otoritas tersebut adalah: Otoritas Tradisional Otoritas tradisional disahkan oleh kesucian tradisi. Kemampuan dan hak untuk mengatur diwariskan melalui keturunan. Tidak mengubah waktu, tidak memfasilitasi perubahan sosial, cenderung tidak rasional dan tidak konsisten, dan melanggengkan status quo. Bahkan, Weber menyatakan: "Pembentukan undang-undang baru yang berlawanan norma-norma tradisional dianggap tidak mungkin pada prinsipnya." Otoritas tradisional biasanya diwujudkan dalam feodalisme atau patrimonialisme. Otoritas Kharismatik Otoritas karismatik ditemukan dalam diri seorang pemimpin dimana misi dan visinya menginspirasi orang lain. Hal ini didasarkan pada karakteristik yang dirasakan oleh seorang individu. Weber melihat seorang pemimpin yang kharismatik sebagai kepala dari gerakan sosial baru, dan satu menanamkan dengan ilahi atau kekuatan gaib, seperti nabi agama. Dalam hal ini, Weber tampaknya mendukung otoritas karismatik, dan menghabiskan banyak waktu membicarakannya. Dalam sebuah studi tentang karisma dan agama, Riesebrodt berpendapat bahwa Weber juga berpikir karisma bermain yang kuat - jika tidak terpisahkan peran dalam sistem otoritas tradisional. Dengan demikian, Weber untuk mendukung otoritas karismatik sangat kuat, terutama dalam berfokus pada apa yang terjadi dengan kematian atau penurunan dari seorang pemimpin yang kharismatik. Otoritas karismatik adalah "dirutinkan" dalam berbagai cara menurut Weber: pesanan traditionalized, staf atau 
Adapun pengertian akuntabilitas adalah perihal tanggung jawab, keadaan dapat diminta pertanggung jawaban. ${ }^{3}$ Mark Boven memaknai akuntabilitas umumnya terkait dengan kewajiban untuk menjelaskan dan menjustifikasi suatu perbuatan atau keputusan yang diakibatkan oleh diskresi yang dimiliki individu. ${ }^{4}$ Untuk meningkatkan akuntabilitas tersebut ada tiga hal yang mesti dijalankan agar interaksi publik dan pejabat terpenuhi. Pertama, pejabat berkewajiban untuk melaporkan berbagai aktivitas kepada publik. Kedua, publik (melalui perwakilan- mempunyai hak untuk menanyakan apabila terdapat data dan informasi yang belum cukup. Ketiga, Publik melalui wakilnya mempunyai kekuasaan untuk menilai laporan tersebut menerima atau menolaknya. ${ }^{5}$

\section{Otoritas Kepala Sekolah dilembaga Pendidikan}

Kepala sekolah merupakan ujung tombak utama dan pertama dalam meningkatkan kualitas lembaga pendidikan. Dibantu dengan pihak yang berada di dalamnya seperti meliputi pegawai, KTU dan guru. Mereka adalah warga sekolah mempunyai otonomi dan tanggung jawab lebih besar atas penggunaan sumber daya sekolah guna memecahkan masalah sekolah dan menyelenggarakan aktivitas pendidikan yang efektif demi perkembangan jangka panjang sekolah. Prinsip seperti ini sama dengan sistem MBS ( Manajemen Berbasis Sekolah). Sekolah mempunyai peran yang sangat central dalam mengatur seluruh sistem yang berlaku di lembaga pendidikan, termasuk dalam hal ini mutu pengelolaan keuangan. ${ }^{6}$

Dalam hal menajemen keuangan lembaga pendidikan ( sekolah), peranan Kepala sekolah sebagai otorisator. Dalam pelaksanaannya, manajemen keuangan

pengikut berubah menjadi hukum atau "estate-seperti" (tradisional) staf, atau arti karisma sendiri mungkin mengalami perubahan. Otoritas Rasional-Legal Legal-rasional, kekuasaannya dipegang oleh suatu keyakinan formalistik isi hukum (hukum) atau hukum alam (rasionalitas). Ketaatan tidak diberikan kepada individu tertentu pemimpin - apakah tradisional atau karismatik - tetapi satu set prinsip-prinsip seragam. Menurut Weber contoh terbaik-hukum otoritas rasional adalah birokrasi (politik atau ekonomi). Bentuk otoritas ini sering ditemukan di negara modern, kota pemerintah, swasta dan perusahaan publik, dan berbagai asosiasi sukarela. Bahkan, Weber menyatakan bahwa "perkembangan negara modern memang identik dengan pejabat dan modern seperti organisasi birokrasi, perkembangan kapitalisme modern identik dengan meningkatnya birokratisasi usaha ekonomi-

${ }^{3}$ Depertemen, Kamus Besar... h. 32. 2009), h. 30.

${ }^{4}$ Mark Boven dalam Wijayanto, Korupsi Mengorupsi Indonesia ( Jakarta: Gramedia,

${ }^{5}$ Ibid., h. 31

${ }^{6}$ Nurkolis, Manajemen berbasis sekolah (Jakarta: Grasindo, 2002), h.4. 
menganut asas pemisahan tugas antara fungsi otorisator, ordonator, dan bendaharawan. Otorisator adalah pejabat yang diberi wewenang untuk mengambil tindakan yang mengakibatkan penerimaan dan pengeluaran anggaran. Ordonator adalah pejabat yang berwenang melakukan pengujian dan memerintahkan pembayaran atas segala tindakan yang dilakukan berdasarkan otorisasi yang telah ditetapkan. Bendaharawan adalah pejabat yang berwenang melakukan penerimaan, penyimpanan, dan pengeluaran uang serta diwajibkan membuat perhitungan dan pertanggungjawaban. Sebagai otorisator dan dilimpahi fungsi ordonator untuk memerintahkan pembayaran. Namun, tidak dibenarkan melaksanakan fungsi bendaharawan karena berkewajiban melakukan pengawasan ke dalam. Sedangkan bendaharawan, di samping mempunyai fungsi-fungsi bendaharawan, juga dilimpahi fungsi ordonator untuk menguji hak atas pembayaran.

Kepala Sekolah juga berlaku seorang manajer keuangan sekolah, yang berkewajiban untuk menentukan keuangan sekolah, cara mendapatkan dana untuk infrastruktur sekolah serta penggunaan dana tersebut untuk membiayai kebutuhan sekolah. Sebagai Otorisator dan juga yang bertindak sebagai seorang manajer keuangan, bertugas antara lain:

1. Mengelola perencanaan perkiraan.

2. Memusatkan perhatian pada keputusan investasi dan pembiayaannya

3. Mengatur kerjasama dengan pihak lain

4. Penggunaan keuangan dan mencari sumber dananya ${ }^{7}$

Seorang otorisator keuangan, kepala sekolah harus mempunyai pikiran yang kreatif dan dinamis. Karena pengelolaan yang berhubungan dengan masalah keuangan dinilai sangat penting dalam penyelenggaraan kegiatan sekolah. Adapun yang harus dimiliki oleh seorang otorisator keuangan yaitu strategi keuangan. Strategi tersebut antara lain:

7 Mooza alkaz, "Makalah Manajemen Keuangan" didapat dari http://moozaalkaz.blogspot.co.id/2013/01/makalah-manajemen-keuangan-pendidikan.html, internet (di akses tanggal 08 Nopember 2016). 


\section{a. Strategic Planning}

Berpedoman keterkaitan antara tekanan internal dan kebutuhan ekternal yang datang dari luar. Terkandung unsur analisis kebutuhan, proyeksi, peramalan, ekonomin dan financial.

b. Strategic Management

Upaya mengelolah proses perubahan, seperti: perencanaan, strategis, struktur organisasi, kontrol, strategis dan kebutuhan primer.

c. Strategic Thinking

Sebagai kerangka dasar untuk merumuskan tujuan dan hasil secara berkesinambungan.

\section{Proses Penyusunan RAPBS}

Kepala sekolah juga bertanggung secara internal untuk menyusun Rencana Anggaran Pendapatan dan Belanja Sekolah (RAPBS) harus berdasarkan pada rencana pengembangan sekolah dan merupakan bagian dari rencana operasional tahunan. RAPBS meliputi penganggaran untuk kegiatan pengajaran, materi kelas, pengembangan profesi guru, renovasi bangunan sekolah, pemeliharaan, buku, meja dan kursi. Penyusunan RAPBS tersebut harus melibatkan guru, komite sekolah, staf TU dan komunitas sekolah. Anggaran memiliki dua sisi, yaitu sisi penerimaan dan pengeluaran. Sisi pengeluaran menggambarkan perolehan atau besarnya dana yag diterima oleh lembaga dari setiap sumber dana, misalnya dari pemerintah, masyarakat, orang tua peserta didik dan sumber- sumber lainnya. Sedangkan sisi pegeluaran menggambarkan besarnya biaya yang harus dikeluarkan untuk tiap komponen program. Istilah yang lazim untuk pengeluaran anggaran adalah dana rutin dan dana pembangunan (recurrent expenditure dan capital expenditure). ${ }^{8}$ Dalam rangka menentukan alokasi anggaran pendidikan, ada dua hal penting yang harus diperhitungkan, yaitu 1) menginventarisasikan sumber dana pendidikan dan 2) menentukan skala prioritas terhadap berbagai kegiatan yang akan dilaksanakan. ${ }^{9}$ RAPBS perlu

\footnotetext{
${ }^{8}$ Tim Dosen Administrasi Pendidikan Universitas Pendidikan Indonesia, Manajemen Pendidikan ( Bandung : Alfabeta, 2003). h.258-259.

${ }_{9}$ Matin, Manajemen Pembiayaan Pendidikan Konsep Aplikasi (Jakarta: Raja Grafindo Persada, 2004). h.119.
} 
disusun pada setiap tahun ajaran sekolah dengan memastikan bahwa alokasi anggaran bisa memenuhi kebutuhan sekolah secara optimal.

Prinsip Penyusunan RAPBS, antara lain:

a. RAPBS harus benar-benar difokuskan pada peningkatan pembelajaran murid secara jujur, bertanggung jawab, dan transparan.

b. RAPBS harus ditulis dalam bahasa yang sederhana dan jelas, dan dipajang di tempat terbuka di sekolah.

c. Dalam menyusun RAPBS, sekolah sebaiknya secara saksama memprioritaskan pembelanjaan dana sejalan dengan rencana pengembangan sekolah.

d. Proses Penyusunan RAPBS meliputi:

1. Menggunakan tujuan jangka menengah dan tujuan jangka pendek yang ditetapkan dalam rencana pengembangan sekolah

2. Menghimpun, merangkum, dan mengelompokkan isu-isu dan masalah utama ke dalam berbagai bidang yang luas cakupannya,

3. Menyelesaikan analisis kebutuhan,

4. Memprioritaskan kebutuhan,

5. Mengonsultasikan rencana aksi yang ditunjukkan/dipaparkan dalam rencana pengembangan sekolah,

6. Mengidentifikasi dan memperhitungkan seluruh sumber pemasukan,

7. Menggambarkan rincian (waktu, biaya, orang yang bertanggung jawab, pelaporan, dsb.), dan mengawasi serta memantau kegiatan dari tahap perencanaan menuju tahap penerapan hingga evaluasi.

\section{Akuntabilitas dana Pendidikan}

Kepala sekolah wajib menyampaikan laporan di bidang keuangan terutama mengenai penerimaan dan pengeluaran keuangan sekolah. Pengevaluasian dilakukan setiap triwulan atau per semester. Dana yang digunakan akan dipertanggungjawabkan kepada sumber dana. Jika dana tersebut diperoleh dari orang tua siswa, maka dana tersebut akan dipertanggungjawabkan oleh kepala sekolah kepada orang tua siswa. Begitu pula jika dana tersebut bersumber dari pemerintah maka akan dipertanggungjawabkan kepada pemerintah. 
Dalam pengelolaan dana pendidikan perlu memperhatikan sejumlah prinsip. Undang-undang No 20 Tahun 2003 pasal 48 menyatakan bahwa pengelolaan dana pendidikan berdasarkan pada prinsip keadilan, efisiensi, transparansi. ${ }^{10}$ Disamping itu prinsip efektivitas juga perlu mendapat penekanan. Berikut ini dibahas masing-masing prinsip tersebut, yaitu transparansi, akuntabilitas, efektivitas, dan efisiensi.

1. Transparansi

Transparan berarti adanya keterbukaan. Transparan di bidang manajemen berarti adanya keterbukaan dalam mengelola suatu kegiatan. Di lembaga pendidikan, bidang manajemen keuangan yang transparan berarti adanya keterbukaan dalam manajemen keuangan lembaga pendidikan, yaitu keterbukaan sumber keuangan dan jumlahnya, rincian penggunaan, dan pertanggungjawabannya harus jelas sehingga bisa memudahkan pihak-pihak yang berkepentingan untuk mengetahuinya. Transparansi keuangan sangat diperlukan dalam rangka meningkatkan dukungan orangtua, masyarakat dan pemerintah dalam penyelenggaraan seluruh program pendidikan di sekolah. Disamping itu transparansi dapat menciptakan kepercayaan timbal balik antara pemerintah, masyarakat, orang tua siswa dan warga sekolah melalui penyediaan informasi dan menjamin kemudahan di dalam memperoleh informasi yang akurat dan memadai. Beberapa informasi keuangan yang bebas diketahui oleh semua warga sekolah dan orang tua siswa misalnya rencana anggaran pendapatan dan belanja sekolah (RAPBS) bisa ditempel di papan pengumuman di ruang guru atau di depan ruang tata usaha sehingga bagi siapa saja yang membutuhkan informasi itu dapat dengan mudah mendapatkannya. Orang tua siswa bisa mengetahui berapa jumlah uang yang diterima sekolah dari orang tua siswa dan digunakan untuk apa saja uang itu. Perolehan informasi ini menambah kepercayaan orang tua siswa terhadap sekolah.

2. Akuntabilitas

Akuntabilitas adalah kondisi seseorang yang dinilai oleh orang lain karena kualitas performansinya dalam menyelesaikan tugas untuk mencapai tujuan yang menjadi tanggung jawabnya. Akuntabilitas di dalam manajemen keuangan berarti penggunaan uang sekolah dapat dipertanggungjawabkan sesuai dengan

${ }^{10}$ lihat Undang - Undang Republik Indonesia nomor 20 tahun 2003 Tentang Sistem Pendidikan Nasional. 
perencanaan yang telah ditetapkan ${ }^{11}$. Berdasarkan perencanaan yang telah ditetapkan dan peraturan yang berlaku maka pihak sekolah membelanjakan uang secara bertanggung jawab. Pertanggungjawaban dapat dilakukan kepada orang tua, masyarakat dan pemerintah. Ada tiga pilar utama yang menjadi prasyarat terbangunnya akuntabilitas, yaitu (1) adanya transparansi para penyelenggara sekolah dengan menerima masukan dan mengikutsertakan berbagai komponen dalam mengelola sekolah , (2) adanya standar kinerja di setiap institusi yang dapat diukur dalam melaksanakan tugas, fungsi dan wewenangnya, adanya partisipasi untuk saling menciptakan suasana kondusif dalam menciptakan pelayanan masyarakat dengan prosedur yang mudah, biaya yang murah dan pelayanan yang cepat

3.

Efektivitas

Efektif seringkali diartikan sebagai pencapaian tujuan yang telah ditetapkan. Garner mendefinisikan efektivitas lebih dalam lagi, karena sebenarnya efektivitas tidak berhenti sampai tujuan tercapai tetapi sampai pada kualitatif hasil yang dikaitkan dengan pencapaian visi lembaga. Effectiveness "characterized by qualitative outcomes". Efektivitas lebih menekankan pada kualitatif outcomes. Manajemen keuangan dikatakan memenuhi prinsip efektivitas kalau kegiatan yang dilakukan dapat mengatur keuangan untuk membiayai aktivitas dalam rangka mencapai tujuan lembaga yang bersangkutan dan kualitatif outcomes-nya sesuai dengan rencana yang telah ditetapkan.

4.

Efisiensi

Efisiensi berkaitan dengan kuantitas hasil suatu kegiatan. Efficiency "characterized by quantitative outputs" Efisiensi adalah perbandingan yang terbaik antara masukan (input) dan keluaran (out put) atau antara daya dan hasil. Daya yang dimaksud meliputi tenaga, pikiran, waktu, biaya. Perbandingan tersebut dapat dilihat dari dua hal:

\footnotetext{
${ }^{11}$ Dalam kerangka sederhana, dalam laporan keuangan dan akuntasi adalah urat nadi dalam penyelenggraan pendidikan. Jadi apabila laporan keuangan kurang sehat tentu akan mempengaruhi operasional lembaga pendidikan. Lihat Indra Bastian, Akutansi Pendidikan (Yogyakarta: Erlangga, 2006), h.210.
} 
a) Dilihat Dari Segi Penggunaan Waktu, Tenaga Dan Biaya

Kegiatan dapat dikatakan efisien kalau penggunaan waktu, tenaga dan biaya yang sekecil-kecilnya dapat mencapai hasil yang ditetapkan. .

b) Dilihat Dari Segi Hasil

Kegiatan dapat dikatakan efisien kalau dengan penggunaan waktu, tenaga dan biaya tertentu memberikan hasil sebanyak-banyaknya baik kuantitas maupun kualitasnya.

Tingkat efisiensi dan efektivitas yang tinggi memungkinkan terselenggaranya pelayanan terhadap masyarakat secara memuaskan dengan menggunakan sumber daya yang tersedia secara optimal dan bertanggung jawab. ${ }^{12}$

\section{Penutup}

Pengelolaan dana pendidikan dengan baik akan berpengaruh kepada langsung kepada output dari lembaga pendidikan itu sendiri. Sebagai seorang otoritator, kepala sekolah mempunyai peranan yang strategis untuk menjaga keluar masuknya dana dilembaganya. Sinergitas dengan segenap elemen pendidikan menjadi kekuatan tersendiri. Disisi yang lain keberadaan komite sekolah selalu menjadi pemantau, pengawas dan pembimbing. Karena untuk menjalan fungsi pengatur keuangan, kepala sekolah dapat mampu berintegrasi kepada semua unsur. Kepala sekolah juga dituntuk dinamis dan terbuka terhadap semua masukan dan pandangan untuk mengembangkan sekolah.

Pada porsi yang lain, prinsip akuntabilitas tetap dijunjung tinggi. Karena untuk menjaga kepecayaan masyarakat pada lembaga pedidikan( sekolah) Sikap tranparansi dan prinsip akuntabilitas tetap dijaga. Ini bukan hanya menjaga dana tetap mengalir dan dipergunakan sesuai dengan RAPBS tapi juga langkah konkrit menciptakan suasana bersih. Jauh dari praktek KKN ( Korupsi, kolusi dan nepotisme. Ditinjau dari kualiatas manajerial, berjalannya sistem sekolah berjalan dengan baik.

12 Mooza, "Makalah.. didapat dari http://mooza-alkaz.blogspot.co.id/2013/01/makalahmanajemen-keuangan-pendidikan.html, internet (di akses tanggal 09 Nopember 2016). 


\section{Pustaka Acuan}

Abraham, Harold D Laswel. Power and Society . USA: Transcation Publisher, 1950.

alkaz, Mooza. "Makalah Manajemen Keuangan" didapat dari http://moozaalkaz.blogspot.co.id/2013/01/makalah-manajemen-keuanganpendidikan.html.

Bastian, Indra. Akutansi Pendidikan. Yogyakarta: Erlangga, 2006.

Depertemen Pendidikan Nasional. Kamus Besar Bahasa Indonesia. Jakarta: Pustaka Utama, 2008.

M, Arifin. Ilmu Pendidikan Islam Jakarta : Bumi Aksara, 1989.

Matin. Manajemen Pembiayaan Pendidikan Konsep Aplikasi. Jakarta: Raja Grafindo Persada, 2004.

Nurkolis. Manajemen berbasis sekolah. Jakarta: Grasindo, 2002.

Wijayanto. Korupsi Mengorupsi Indonesia. Jakarta: Gramedia, 2009.

Tim Dosen Administrasi Pendidikan Universitas Pendidikan Indonesia. Manajemen Pendidikan. Bandung : Alfabeta, 2003. 